\title{
Příspěvek českobudějovických biskupů k péči o nemocné $v$ jejich sídelním městě $v$ letech $1785-1883^{1}$
}

Rudolf Svoboda

\section{Několik slov úvodem}

V odborné literatuře zatím byla $\mathrm{v}$ případě starosti o potřebné věnována pozornost zejména charitativní činnosti, která byla v celé českobudějovické diecézi v prvním století její existence rozvíjena kromě individuálních aktivit biskupů také místními farními charitami, které byly podle nařízení státu zřizovány v josefínské době a svoji činnost vykonávaly i v následujícím století. $^{2}$

Zatím vcelku opomíjeným tématem je angažmá místní církve v oblasti péče o nemocné. Obecně lze říci, že v čase vzniku českobudějovické diecéze na konci osmnáctého století ještě neexistovalo jasné dělení mezi charitativními a zdravotními institucemi. $\mathrm{K}$ jasnému oddělování a hlavně $\mathrm{k}$ rozšíření počtu nemocnic docházelo až postupně $\mathrm{v}$ průběhu devatenáctého století, přičemž zásluhu na tom měla nejen nařízení státu starající se o zvýšení kvality života a zdravotní péče a o dohled nad kvalifikacemi lékařŭ, ale také intenzivnější finanční podpora ze strany místních samospráv a církve. ${ }^{3}$

V této krátké studii budeme zmíněnou problematiku ilustrovat na aktivitách prvních čtyř českobudějovických biskupů Jana Prokopa Schaaffgotsche, Arnošta Konstantina Růžičky, Josefa Ondřeje Lindauera a Jana Valeriána Jirsíka zejména $v$ souvislosti s jejich starostí o nemocné v sídelním městě diecéze.

\section{Jan Prokop Schaaffgotsche a Arnošt Konstantin Růžička}

Pro prvního českobudějovického biskupa Jana Prokopa Schaaffgotsche (1785-1813) 4 se stala péče o nemocné jednou z významných aktivit jeho episkopátu. Věděl velmi dobře, že situace v nově založené diecézi (1785) i v jeho sídelním městě není v tomto ohledu př́liš dobrá. $Z$ oficiálních dokumentů je patrné, že v době jeho nástupu do funkce se v diecézi

\footnotetext{
1 Tato studie vychází s laskavým přispěním Grantové agentury České republiky jako dílčí výstup projektu 15-09797S "Jan Valerián Jirsík: život a teologické dílo“.

2 Srov. Rudolf SVOBODA, Počátky českobudějovické diecéze, Praha: Vyšehrad, 2014; Martina HALÍŘOVÁ, Role duchovních v chudinské a nalezenecké péči, Historie - Otázky - Problémy 2/2009 (Od barokní piety k interiorizaci víry?

Problémy katolického osvícenství v českých zemích), s. 133-137.

3 Srov. Zdeňka STOKLÁSKOVÁ, Osvícenství a vznik veřejného zdravotnictví, in: Post tenebras spero lucem. Duchovní tvár českébo a moravskébo osvícenství, eds. Daniela TINKOVÁ - Jaroslav LORMAN, Praha: Cassablanca - Filozofická fakulta UK, 2009, s. 88-105; ještě podrobněji k tématu Daniela TINKOVÁ, Zákeřná mefitis. Zdravotnípolicie a veřejná bygiena v pozdně osvícenských Čechách, Praha: Argo, 2013.

4 K životu a především biskupskému působení vyšly monografie Rudolf SVOBODA, Jan Prokop Schaaffgotsche: První biskup českobudějovický, Brno: L. Marek, 2009 a Rudolf SVOBODA, Johann Prokop Schaffgotsch. Das Leben eines böbmischen Prälaten in der Zeit des Josepbinismus (= Beiträge zur Kirchen- und Kulturgeschichte 25), Frankfurt am Main, Berlin, Bern, Bruxelles, New York, Oxford, Wien: Peter Lang, 2015.
} 
nacházelo osmdesát pět chudobinců, které možná jakousi zdravotní péči poskytovaly, a pouhé tři nemocnice. ${ }^{5}$

Nutnost pomáhat nemocným zdůraznil biskup Schaaffgotschejiž ve svém prvním pastýřském listě z 1. ledna 1786 adresovaném obyvatelům diecéze, v němž zcela jasně formuluje i potřebu péče o duchovní stránku každého věřícího. ${ }^{6}$ Postarat se o lepší zdravotní péči obyvatel patřilo mimo jiné i k poslání duchovního, jak jej viděl tehdejší josefinistický stát. ${ }^{7}$

Bohužel nová diecéze nebyla bohatá. Sám Schaaffgotsche neměl prakticky jiné př́imy než státem vyplácený nepř́lišs vysoký biskupský plat. V neklidných časech napoleonských válek bylo velmi obtížné realizovat kvůli nedostatku prostředků prakticky jakékoli stavební či nadační projekty. Informaci o neutěšeném hmotném zajištění zdravotní péče podává zpráva z generální vizitace z konce Schaaffgotschova téměř třicetiletého episkopátu, v níž biskup konstatuje, že v nemocnicích a útulcích pro chudé žije 361 lidí, což v poměru k přibližně tři čtvrtě milionové diecézi opravdu nebylo mnoho. ${ }^{8} \mathrm{Na}$ druhou stranu však uvádí, že se kněží starají o nemocné po duchovní stránce, takže žádný nemocný nezemřel bez zaopatření vinou odpovědného duchovního správce. ${ }^{9}$

Osobní angažmá biskupa Schaaffgotsche je možné vidět především v jeho starosti o nemocné v Českých Budějovicích. V čase zakládání biskupstvízde zajištovaly alespoňjakousi zdravotní péči dvě instituce:Jednak existoval již od počátku 14. století špitál s kostelem sv. Václava, který

5 Srov. Archivio Segreto Vaticano (dále jen ASV), Archivium Consistorialis (dále jen AC), Acta Congregationis Consistorialis 1785, Pars I, 1785 Budvicen. Erectionis in Episcopalium, fol. 273-297; ASV, AC, Processus Consistorialis - Processus Inquisitionis super statu Ecclesiae Budvicen. nunc primum auctoritate Apostolica in Cathedralem erigendae, et super qualitatibus Rmi. Dni. Joannis Procopii Comitis de Schafgotsch Metropolitanae Ecclesiae Olomucen. Canonici ad Episcopatum Budvicen. dicta auctoritate promovendi 1785, fol. 137-183; Congregazione del Consilio, Relationes Dioecesium (fine sec. XVI - 1890 circa), Budvicen., Ceske Budejovice - Budweis (Bohemia), sign. 153, fol. 138-147.

6 Přepis pastýřského listu Jana Prokopa Schaaffgotsche z 1. ledna 1786 viz Franz MARDETSCHLÄGER, Kurz gefasste Geschichte des Bistums und der Diöcese Budweis zur Jubiläumsfeier ibres bundertjäbrigen Bestebens, Budweis: Franz Mardetschläger, 1885, s. $274-283$.

Koncept pastýřského listu viz SOA Třeboň, Biskupský archiv České Budějovice (dále BA ČB), Pastýřské listy biskupa Schafgotsche, 1786-1795, sign. II/1/b/10, kart. 11.

Text zní takto: „Sitis sal terae, cujus virtute condiantur fideles vestri. Nolite distinguere inter Judaeum, et Graecum, sed omnes eadem charitate, eodem amore, eodem zelo complectamini. Sitis miseris solamen, affictis consolatio, pauperibus refugium, infirmis adjutorium, debilibus fortitudo, dubitantibus consilium, ignorantibus instructio, oppressis defensio, innocentiae custodia, lapsis resurrectio, spiritualiter mortuis vita; Vigilate in omnibus laborate opus faciatis Evangelistae, ministeriumque vestrum implete, coram Deo et Christo Jesu... “( „Necht' jste solí země, jejíž silou jsou ochuceni vaši věřící. Nerozlišujte mezi Židem a Řekem, nýbrž všechny zahrnujte touž úctou, touž láskou a touž horlivostí. Bud'te neštastným útěchou, zarmouceným potěšením, chudým útočištěm, nemocným pomocí, slabým posilou, pochybujícím rádcem, nezralým poučením, utlačovaným obranou, nevinným strážcem, padlým např́ímením, duchovně mrtvým životem; bud'te ve všem bdělí a pracujte, at činíte dílo Evangelisty, a naplňujte svůj úřad před Bohem a Ježíšem Kristem...", překlad autora). Viz také Rudolf SVOBODA, Seid den Armen Zuflucht und den Kranken Hilfe, in:, Theorie und Praxis der Karitativen Arbeit, Einfuibrung in die Problematik, Praktische Reflexion und Anwendung, eds. Michal OPATRNÝ - Markus LEHNER, České Budějovice: Teologická fakulta JU (Edice Scientia Bd. 5), 2010, s. 10-26.

7 Srov. Claude MICHAUD, Der Josephinismus in der Habsburgermonarchie (1740-1790), in: Die Geschichte des Christentums: Aufklärung, Revolution, Restauration (1750-1830), ed. Norbert BROX, Freiburg im Breisgau - Basel - Wien: Herder, 2000, s. 23-24; Rudolf LEEB - Maximilian LIEBMANN - Georg SCHEIBELREITER - Peter G. TROPPER, Geschichte des Christentums in Österreich. Von der Spätantike bis zur Gegemwart, Wien: Verlag Carl Ueberreuter, 2003, s. 296-297; Martina HALÍŘOVÁ, Role duchovních v chudinské a nalezenecké péči, s. 133-134.

8 Srov. Österreichisches Staatsarchiv Wien, Haus-, Hof- und Staatsarchiv (dále jen HHSA), Kaiser-Franz-Akten 215, sign. ATOeStA/HHSTA KA KFA, fol. 524-571.

Srov. Kurt Augustin HUBER, Der Budweiser bischöfliche Visitationsbericht von 1811, in: Archiv für Kirchengeschichte von BöbmenMäbren-Scblesien VII, Festschrift zur qweiten Säkularfeier des Bistums Budweis 1785-1985, ed. Kurt Augustin HUBER, Königstein im Taunus: Institut für Kirchengeschichte von Böhmen-Mähren-Schlesien, 1985, s. 72.

9 Srov. Österreichisches Staatsarchiv Wien, HHSA, Kaiser-Franz-Akten 215, sign. AT-OeStA/HHSTA KA KFA, fol. 397-398;

SOA Třeboň, BA ČB, Zpráva biskupa zemskému guberniu o stavu diecéze, 1811, $\mathbb{S}$ 2, sign. II/1/b/7, kart. 10. 
byl však v roce 1786 zrušen, ${ }^{10}$ jednak tu byl městský chudobinec (Armeninstitut) v dnešní Krajinské tř́dě, založený v roce 1781, který krátce spravovaly sestry z řádu sv. Františka. Od roku 1787 byla péče $\mathrm{v}$ chudobinci rozšířena o nemocniční ošetřování a od roku 1793 byl spojený s městskou nemocnicí. Budova však měla velmi malou kapacitu, a pro tehdy pětitisícové město proto rozhodně nebyla situace nemocniční péče dobrá. ${ }^{11}$

Schaaffgotschovi se nepodařilo situaci s nemocniční péčí ve vlastním sídelním městě vyřešit, a to přesto, že úzce spolupracoval $s$ představiteli města $v$ čele $s$ purkmistrem Franzem Daudlebským von Sterneck, o němž je známo, že věnoval značnou pozornost kromě školství právě chudinské a zdravotní péči. ${ }^{12}$ Přes velkou snahu se nepodařilo sehnat dostatek prostředků na společný projekt stavby nové nemocnice.

Do konce Schaaffgotschova episkopátu platilo, že o fungování stávající „nemocnice“ se po materiální stránce staralo město, církev zase zajištovala duchovní správu, v níž se biskup osobně angažoval pravidelnými návštěvami a zaopatřováním nemocných, což potvrzují zápisy v tzv. Matrice biskupských prací. ${ }^{13} \mathrm{Na}$ potřebnost nové nemocnice však nikdy nezapomněl, o čemž svědčí jeho závět z roku 1813, ve které věnoval na její výstavbu významnou část svého odkazu, částku 3815 zlatých. ${ }^{14}$ Pro úplnost je třeba dodat, že právě jeho starost o nemocné a umírající se stala součástí jeho duchovního odkazu pro prřšstí generace. ${ }^{15}$

Schaaffgotschův nástupce Arnošt Konstantin Růžička (1813-1845), který mu jako generální vikář stál po téměř dvě desetiletí po boku, pokračoval v jeho odkazu. ${ }^{16}$ Také on čelil v diecézi faktu nedostatečného počtu zdravotnických institucí. ${ }^{17}$ Stejně jako jeho předchůdce vyzýval věřící $\mathrm{k}$ tomu, aby konali skutky křestanské lásky mimo jiné i obsluhováním nemocných. ${ }^{18}$

10 Srov. Daniel KOVÁŘ, Zdravotní péče, in: Encyklopedie Českých Budějovic (dále jen $E \check{C} B$ ), České Budějovice: Statutární město České Budějovice - Nebe, 2. vydání, 2006, s. 636. Jinde se uvádí rok zrušení špitálu 1796. Viz Daniel KOVÁŘ - Diana ŠMAJCLOVÁ - Jiří ČERNÝ, Nemocnice, $E \check{C} B$, s. 343. Tuto nesrovnalost lze vysvětlit následujícím způsobem: Rokem 1786 odešly z města františkánky, a tím skončilo jejich angažmá ve špitálu. Ten s podporou města fungoval pravděpodobně ještě deset let.

Poté byl definitivně zrušen.

11 Srov. Karel PLETZER, Chudobinec, EČB, s. 184; Jiř́i KROPÁČEK - Oldřich MIKULA, Sociální péče, EČB, s. 510.

12 Srov. Robert SAK - Václav BU゚ŽEK - Jiří DVOŘÁK - Miroslav NOVOTNÝ, Dějiny města, EČB, s. 92.

13 Podle zápisů v matrice biskupských prací biskup navštívil a zaopatřil celkem 125 nemocných. Viz S. Penitentia Eucharistia et Unctionis sacramentis, SOA Třeboň, BA ČB Matrika biskupských prací - Matrica seu Liber functionum episcopalium, 1786-1852, inv. č. 17, kniha 17. Franz Mardetschläger uvádí 122 zaopatřených věřících. Srov. Franz MARDETSCHLÄGER, Kurz gefasste

Geschichte, s. 14.

O osobních návštěvách nemocných svědčí také tzv. biskupský diár. SOA Třeboň, BA ČB, Makulář matriky biskupských prací

- Macularie diarii et functionum episcopalium, 1789-1799, inv. č. 16, kniha 16.

14 Srov. Willibald LADENBAUER, Das Soziale Wirken der katholischen Kirche in der Diöcese Budweis (Königreich Böbmen) von Dr. P. Willibald Ladenbaner, Wien: Commissions-Verlag von Maner a Co., 1899 (= Das Sociale Wirken der Katholischen Kirche in Oesterreich. Im Auftrage der Leo-Gesellschaft und mit Unterstützung von Mitarbeitern herausgegeben von Prof. Dr. Franz M. Schingler, IX. Band: Diöcese Budweis), s. 257; Rudolf SVOBODA, Jan Prokop Schaaffgotsche, s. 247-248; Franz MARDETSCHLÄGER, Kur gefasste Geschichte, s. 16.

15 Srov. Biographisches Lexikon des Kaisertbums Oesterreich enthaltend die Lebensskizzen der denkwürdigen Personen, welche seit 1750 in den österreichischen Kronländern geboren wurden oder darin gelebt und gewirkt baben, ed. Constantin WÜRZBACH, Wien: Druck und Verlag der k. k. Hof- und Staatsdruckerei, 1875, s. 83; Jaroslav KADLEC, Českobudějovická diecéže, České Budějovice: Sdružení Jana Nepomuka Neumana - Setkání, 1995, s. 28; Rudolf SVOBODA, Legenda o dobrém pastýři, Verba theologica 1/2009, s. 24-29.

16 K životu A. K. Růžičky viz monografii Rudolf SVOBODA, Arnošt Konstantin Růžičcka: Josefinista na českobudějovickém biskupském stolci, České Budějovice: Jih, edice Středoevropské dějiny, sv. 4, 2011.

17 ASV, AC, Processus Consistorialis - Processus Inquisitionis super Qualitatibus Rmi Dni Ernesti Ruziczka Cathedralis Ecclesiae Budvicensis Vicarii Generalis et Officialis ab Augustissimo Austriae Imperatore Francisco I Hungariae Apostolico, ac Bohemiae Rege ad Episcopatum Budvicensem Nominati, ac Promovendi et super Statu Ecclesiae Cathedralis Budvicensis Anno 1815, fol. 98-101. 18 Pastýřský list Arnošta Konstantina Růžičky z prosince 1831. Viz SOA Třeboň, BA ČB, Arnošt Konstantin Rǔžička, Pastýřský list Arnošta Konstantina Růžičky s udělením církevního dispensu od půstu pro postižené cholerou - tisk, 1831, sign. II/2/b/8, kart. 13. 
Ve spolupráci s představiteli Českých Budějovic se nakonec podařilo postavit novou nemocnici, o kterou tak usiloval biskup Schaaffgotsche. Za peníze z jeho odkazu byl v roce 1826 koupen pozemek. Vypracováním plánů byl pověřen stavitel Josef Bednařík. ${ }^{19}$

Položení základního kamene 21. května 1827 se osobně zúčastnil biskup Růžička. Kolaudace dvoupatrové budovy, situované na vnitřním okraji tehdejšího vídeňského předměstí v ústí dnešní ulice Karla IV. na Mlýnskou stoku, se konala 4. ř́jna 1829 a poté byla 24. prosince téhož roku za účasti biskupa slavnostně otevřena. Celkový náklad na stavbu byl 18918 zlatých. Svým dílem přispěl také sám Růžička, který daroval tisíc zlatých. Zbytek zaplatilo město. Budova nesla název Bürgerliches Armen - Kranken und Arbeitshaus a sloužila zároveň i jako chudobinec. Její chod ř́́dili zástupci města, lékařů a církve, duchovním správcem nemocnice byl městský děkan. ${ }^{20}$ Samotný Růžička nadále o chod nemocnice pečoval a na její podporu určil peníze ve své závěti. ${ }^{21}$ Tato instituce se stala něčím, čím se mohlo město v dobrém slova smyslu pochlubit: když České Budějovice 5. zář́ 1834 navštívil císař Ferdinand V., byl mimo jiné zaveden také do nové nemocnice. ${ }^{22}$

\section{Josef Ondřej Lindauer a Jan Valerián Jirsík}

Růžičkův nástupce Josef Ondřej Lindauer (1846-1850) byl sice biskupem pouze krátkou dobu, ale přesto po sobě v tomto ohledu zanechal poměrně zásadní odkaz. ${ }^{23}$ Byl člověkem, který neměl rád v oblasti pomoci potřebným nepromyšlené kroky, jejichž vinou by mohlo dojít ke zbytečnému plýtvání omezenými prostředky.

Jako biskup se snažil v diecézi postupovat systematicky. Využil systému diecézní církevní správy a nařídil představeným třiceti vikariátů, aby každé záŕí posílali kromě zpráv o stavu školství a o podpoře chudých žáků také informace o počtu a podpoře hluchoněmých a slepých a o nemocnicích. ${ }^{24}$ Jeho starost o zřizování nových nemocnic byla dobře známá - konkrétně se mu dařilo podpořit svou autoritou, či dokonce finančně nemocnice ve Strakonicích a v Písku. ${ }^{25}$

19 Nejstarší literární zmínku o tomto projektu viz Ernst Franz RICHTER, Kurzgefaßte Geschichte der k. befreiten allegeit getreuen Berg- und Kreisstadt Böbmisch-Budweis, Budweis: F. Zdarssa, 1859, s. 43-44, 47. Josef Bednařík působil v Českých Budějovicích v letech 1818-1851. Kromě stavby nemocnice realizoval i stavby soukromých domů. Srov. Daniel KOVÁŘ, Stavitelé, EČB, s. 536. 20 Srov. Daniel KOVÁŘ - Diana ŠMAJCLOVÁ - Jiř́ ČERNÝ, Nemocnice, EČB, s. 343; Jiří KROPÁČEK - Oldřich MIKULA, Sociální péče, $E \check{C} B$, s. 510. Karel Pletzer pro novou instituci používá název Armen Kranken und Korrektionsanstalt. Srov. Karel PLETZER, Chudobinec, $E \check{C} B$, s. 184.

21 Podle poslední vůle z roku 1831 i z roku 1844 odkázal Růžička nemocnici tisíc zlatých. Viz poslední vưli biskupa Arnošta Konstantina Růžičky z 22. září 1831 a poslední vůli biskupa Arnošta Konstantina Růžičky z 10. ledna 1844. Srov. SOA Třeboň, BA ČB, Arnošt Konstantin Růžička, Poslední vůle a pozůstalostní řízení, 1831-1848, sign. II/2/a/3, kart. 13; dále také Willibald LADENBAUER, Das Soziale Wirken der katholischen Kirche in der Diöcese Budweis, s. 257, 298; Jiří ČERNÝ - Diana ŠMAJCLOVÁ, Dějiny českobudějovické nemocnice, 1. dúl, (středověk - 1948), České Budějovice: Nemocnice České Budějovice, 2007, s. 18-20; Rudolf SVOBODA, Arnošt Konstantin Rưžička, s. 151-153, 182-183.

22 Srov. Ernst Franz RICHTER, Kurzgefaßte Geschichte, s. 45-47; Karel PLETZER, Návštěvy panovníků a prezidentů, EČB, s. 341; Franz MARDETSCHLÄGER, Kurz gefasste Geschichte, s. 21.

23 K Lindauerovu životu a biskupskému působení viz Rudolf SVOBODA, Josef Ondřej Lindauer - známý i neznámý třetí biskup českobudějovický, Jibočeský sborník historický 82/2013, s. 153-163.

24 Viz Conspectus Relationum, quae singulis mensibus a Vic. For. Officiis ad Reverendissimum Episcopale Consistorium exhibendae sunt. Catalogus Universi Cleri tum Saecularis tum Regularis Episcopalis Dioeceseos Bohemo-Budvicensis $\mathrm{z}$ let $1848-1851$.

25 SOkA Strakonice, Strakonice - Journal oder Merkwürdigkeiten und Vorfälle der Strakonitzer Haupt Schule, 1806-1859, školní kronika; Časopis pro katolické duchovenstvo (dále ČKD) 3/1850, s. 198. 
Nebývalá byla jeho podpora českobudějovické nemocnici, které daroval brzy po svém př́jezdu do města 3 tisíce zlatých. V roce 1849 do ní uvedl Milosrdné sestry sv. Karla Boromejského, což je považováno za jeden z největších počinů jeho episkopátu. $S$ boromejkami měl dlouholetou zkušenost ze svého pražského působení, kde byl jako pražský kanovník přispívajícím členem spolku podporujícího dospělé slepce v Čechách Versorgungs-und Beschäftigungs-Anstaltfür erwacbsene Blinde in Böbmen. Důležitou souvislostí je, že tento spolek je úzce svázán právěs pražskou činnostíboromejek ve prospěch slepých lidíjiž od roku $1837 .{ }^{26}$ Ostatně i v českobudějovické diecézi byly se sestrami dobré zkušenosti, a to z jejich třeboňského působení pod patronací schwarzenberského rodu od roku 1841. Kromě toho se svým způsobem vracely domů, protože samotné počátky boromejek v Čechách jsou svázány s odchodem čtyř žen z Českých Budějovic do francouzského Nancy, odkud se roku 1837 vrátily již jako ráádové sestry. První představená českobudějovických boromejek Karolína, světským jménem Johana, byla sestrou filadelfského biskupa a pozdějšího světce Jana Nepomuka Neumanna. ${ }^{27}$ Podle historika Franze Mardetschlägera př́šlo za Lindauerova episkopátu do Českých Budějovic 14 sester, z nichž 8 pracovalo v nemocnici a $6 \mathrm{v}$ sirotčinci (Weisenbaus). Nemocnici boromejky převzaly do své správy 9. ledna 1850. Pro začátek jejich působení v nemocnici daroval Lindauer 4 tisíce zlatých.$^{28}$ Nemocnici učinil také svým univerzálním dědicem. Ta po biskupově předčasné smrti získala $\mathrm{z}$ jeho odkazu přibližně 24 tisíc zlatých, což byla na tuto dobu opravdu veliká částka. ${ }^{29}$ Vděční obyvatelé města nechali postavit na českobudějovickém staroměstském hřbitově pomník s poděkováním právě za tento velký dar. ${ }^{30}$

\section{Za episkopátu Jana Valeriána Jirsíka (1851-1883) ${ }^{31}$ bylajiž zajištěna základníinstitucionalizace zdravotní péče v diecézi i v jeho sídelním městě a docházelo spíše k následné specializaci}

\footnotetext{
26 Srov. Augustin (Josef) SVOBODA, Milosrdné Sestry, živé vypodobnění Ježíše Krista. Řeč, při slavném činění slibů milosrdných sester ze shromáždění sv. Karla Boromea, ČKD 2/1850, s. 133-150. Řeč byla přednesena 15. srpna 1848 v Praze $\mathrm{v}$ mateřinci sester. Autor byl doktor teologie a kaplan v Lišově. Autor v článku zmiňuje, že od té doby, co v roce 1837 přišly z Francie do Čech, založily nejprve mateřský dům na Malé Straně s nemocnicí. Vypočítává pak dalších devět založených institucí - nemocnic či speciálních ústavů věnujících se sirotků či slepým. Jako poslední z nich zmiňuje nemocnici v Českých Budějovicích: „Konečně v Českých Budějovicích, kdežto ústav jejich šlechetným působením a vlastním velikým nákladem tamního Nejdůstojnějšího biskupa, pana Ondřeje Lindauera a jiných dobrodinců založen jest." Tamtéž, s. 150. Dále viz kupř. Miroslav NOVOTNÝ, Řády a kongregace, $E \check{C} B$, s. 481.

27 Uvádí se, že od roku 1849 byla představenou sester v chudobinci. Zda měla na starosti od roku 1850 i sestry v nemocnici, se nám zatím nepodařilo zjistit. Srov. Eva PĚSTOVÁ, Boromejky - aktivity ve 20. stoletív Praže, České Budějovice, 2015, bakalářská práce, Jihočeská univerzita v Českých Budějovicích, Teologická fakulta, Katedra teologických věd, vedoucí práce Martin Weis, s. 9-11. Autorka vycházela z nepublikovaných rukopisů boromejky Sebastiany Veselské Sestra Karolína, Jan Neuman a 150 let boromejek z roku 2011; dále také Petra PFEFFROVÁ, Sociálně-charitativní dílo spjatés rodným domem J. N. Neumanna, České Budějovice, 2014, bakalářská práce, Jihočeská univerzita v Českých Budějovicích, Teologická fakulta, Katedra teologických věd, vedoucí práce Martin Weis, s. 14.

28 Srov. Jiří ČERNÝ - Dana ŠMAJCLOVÁ, Dějiny českobudějovické nemocnice, s. 10, 25; Franz MARDETSCHLÄGER, Kurz gefasste Geschichte, s. 33, 157-158.

29 Srov. Franz MARDETSCHLÄGER, Kurz gefasste Geschichte, s. 38. Viz také SOA Třeboň, BA ČB, kart. 14.

30 2. října 1854 byl požehnán pomník věnovaný Lindauerovi z vděčnosti budějovických věřících za to, že věnoval velkou část svého jmění na stavbu městské nemocnice, a za povolání boromejek, které se staraly o jejich nemocné. Nestojí však nad hrobem biskupa, nýbrž patnáct kroků od vchodu na hřbitov, dnes přibližně uprostřed jižní části hřbitovního areálu. Pomník vytvořil sochař Emanuel Max. Provedený je v novogotickém stylu ve tvaru konického sloupu, na němž se nachází reliéf biskupského znaku. Opatřen byl nápisem: „Reverendissimo Episcopo Budvicensi ANDREAE IOSEPHO LINDAUER benefactori nosocomii Budvicensis generoso, nato Pilsnae die 29. Nov. 1784, die 4. Junii 1850, 4to Episcopatus sui anno ex hoc saeculo egresso, grata Civitas Budvicensis. Requiescat in pace Domini!" Srov. Franz MARDETSCHLÄGER, Kurzgefasste Geschichte, s. 38-39; Úmrtí, ČKD 3/1850, s. 198.

31 K životu a dílu Jana Valeriána Jirsíka viz Jaroslav KADLEC, Jan Valerián Jirsík, České Budějovice: Setkání, 1993; Rudolf SVOBODA - Soňa KAMENOVÁ - Radka NOVOTNÁ, The Life And Theological Work of Jan Valerián Jirsík - Actual State of Research Issue, Notitiae historiae ecclesiasticae 1/2013, s. 15-19.
} 
zdravotně-sociální pomoci. Př́íkladem může být zejména skutečnost, že boromejky zajištovaly chod nemocnice do 30 . června 1856 , pak byla předána do městské správy, ale řeholnice se nadále na jejím chodu podílely. Církev samozřejmě pokračovala v zajištění duchovní péče o nemocné. Za Jirsíkovy doby došlo v letech 1864 a 1873 k prŕstavbám objektu a zvýšení počtu lůžek. ${ }^{32}$ Ve městě také začaly vznikat soukromé lékařské ordinace a sanatoria. Mezi soukromými lékaři stoupal počet specialistů. Veřejnou péči zajištovali dva fyzikové (lékaři), od roku 1870 byla zř́zena funkce okresního lékaře, který měl dohled nad zdravotní péči na okresní úrovni. Zdravotní péči placenou obcí řídil od roku 1883 městský fyzikus za pomoci dvou městských lékařů. ${ }^{33}$

Přestože by se mohlo zdát, že církev by v této situaci mohla přispívat pouze duchovní péčí o nemocné, biskup byl jiného názoru. Viděl jednu velkou mezeru ve zdravotně-sociálním systému, a tou byla starost o skupinu zcela specificky postižených lidí - o hluchoněmé. Podle dobových úředních zpráv bylo v Čechách více než 4 tisíce hluchoněmých, $\mathrm{z}$ toho $\mathrm{v}$ jeho diecézi více než tisíc. Byl přesvědčený o tom, že je třeba se o tyto lidi postarat a že je zejména dětem třeba zajistit vyučování. Proto vyslal schopného kněze, aby se v Praze pro práci s těmito dětmi vyškolil. V roce 1870 se mu podařilo získat pro výuku hluchoněmých dětí budovu bývalého učitelského ústavu v dnešní Riegrově ulici, kterou slavnostně otevřel 6. listopadu 1871. Českobudějovický ústav hluchoněmých byl pátým zařízením tohoto druhu v českých zemích. Učitelské síly poskytly Školské sestry de Notre Dame z Horažd'ovic. Péče o hluchoněmé děti byla až do biskupovy smrti jeho srdeční záležitostí, což se projevovalo osobní péčí a častými návštěvami. Jako člověk veskrze praktický se Jirsík postaral i o financování ústavu. Založil Spolek pro vydržování ústavu hluchoněmých (1871-1956). Na chod instituce přispívali také soukromí dárci a různé nadace. Samotný ústav se postupně rozrůstal a byl několikrát reorganizován - zatímco v roce 1871 začínal se 14 dětmi a 3 pedagogy, již v roce 1873 zde bylo umístěno 50 dětí a bylo nutno stávající budovu rozširírit. V osmdesátých letech se ročně staral ústav již o více než 80 dětí. ${ }^{34}$

\section{Několik slov závěrem}

Z výše uvedeného se dá ř́ci, že pro první čtyři českobudějovické biskupy byla péče o nemocné podstatnou součástí jejich působení a věnovali se jí se značným osobním nasazením. Nesoustředili se pouze na péči duchovní, ale zasloužili se také o institucionální rozvoj nemocniční péče zejména ve svém biskupském městě. Zcela jistě lze proto říci, že si za to právem zaslouží uznalou vzpomínku budoucích generací.

\footnotetext{
32 Srov. Jiří ČERNÝ - Dana ŠMAJCLOVÁ, Dějiny českobudějovické nemocnice, s. 10, 25; Daniel KOVÁŘ - Diana ŠMAJCLOVÁ - Jiř́ ČERNÝ, Nemocnice, $E \check{C} B$, s. 343.

33 Srov. Daniel KOVÁŘ, Zdravotní péče, EČB, s. 636.

34 Srov. Jaroslav KADLEC, Jan Valerián Jirsîk, s. 77-78; Miroslav NOVOTNÝ, Ústav hluchoněmých, EČB, s. 592;

Franz MARDETSCHLÄGER, Kurz gefasste Geschicbte, s. 68-70. Stanovy Spolku k vydržování ústavu pro hluchoněmé v Českých Budějovicích z roku 1871 a výroční zprávy ústavu do roku 1873 jsou dostupné v SOkA České Budějovice, sign. C 44.
} 


\title{
Příspěvek českobudějovických biskupů $\mathrm{k}$ péči o nemocné $\mathbf{v}$ jejich sídelním městě v letech 1785-1883
}

\begin{abstract}
Abstrakt
Studie se zabývá starostí o nemocné prvních čtyř českobudějovických biskupů Jana Prokopa Schaaffgotsche, Arnošta Konstantina Růžičky, Josefa Ondřeje Lindauera a Jana Valeriána Jirsíka v letech 1785-1883 s důrazem na jejich aktivity v Českých Budějovicích. Studie ukazuje propojení starosti o nemocné s charitativní činností, která byla úzce svázána s duchovenskou péčí v posledních desetiletích osmnáctého století. Následně zachycuje proces postupného oddělování charitativních a zdravotních institucí v průběhu devatenáctého století, přičemž vnějším znakem tohoto procesu byl nárůst počtu nemocnic. Zásluhu na tom měla jednak nařízení státu starající se o zvýšení kvality života a zdravotní péče i o dohled nad kvalifikacemi lékařů, jednak intenzivnější finanční podpora ze strany místních samospráv a samozřejmě také všestranná podpora katolické církve zastoupené svými biskupy.
\end{abstract}

Klíčová slova: České Budějovice, péče o nemocné, duchovní péče, biskupové, 18. století, 19. století

\section{Contribution of Bishops of České Budějovice to Care of the III in their Town of Residence in 1785-1883}

\begin{abstract}
The study deals with the concern of the first four bishops of České Budějovice - Jan Prokop Schaaffgotsche, Arnošt Konstantin Rǔžička, Josef Ondřej Lindauer and Jan Valerián Jirsík - for the ill in 1785-1883, with emphasis on their activities in České Budějovice. The study shows how concern for the ill was linked to works of charity, which were closely connected with spiritual care in the last decades of the eighteenth century. It then captures the process of gradual separation of charity and health institutions in the course of the nineteenth century, whereby an outward sign of this process was an increase in the number of hospitals. This was due to state edicts striving to increase the quality of life, health care as well as supervision over physicians' qualifications, but also to more intensive financial support on the part of local governments, and of course also to the all-round support of the Catholic Church represented by its bishops.
\end{abstract}

Keywords: České Budějovice, care of the ill, spiritual care, bishops, $18^{\text {th }}$ century, $19^{\text {th }}$ century

\section{Kontakt na autora}

doc. ThDr. Rudolf Svoboda, Th.D.

Jihočeská univerzita v Českých Budějovicích

Teologická fakulta, Katedra teologických věd

Kněžská 8, 37001 České Budějovice

svobodar@tf.jcu.cz 